\title{
ARTICLE 153 OF THE FEDERAL CONSTITUTION: GOVERNING PRINCIPLE FOR AFFIRMATIVE POLICY AGAINST SOCIAL INJUSTICE
}

\author{
Wan Ahmad Fauzi Wan Husain'1 \\ ${ }^{1}$ Faculty of Industrial Management, Universiti Malaysia Pahang, 26600 Pahang, Malaysia.
}

ABSTRACT - The special position of Malays and natives of Sabah and Sarawak remains a national debate despite the fact that its position has been lawfully accorded according to Article 153, Federal Constitution. Those who had significantly benefitted from the implementation of policies under Article 153 among non-Malays and non-natives of Sabah and Sarawak, especially from an economic policy, have yet turned up to defend many allegations thrown at the Government. As a matter of fact, many Malays themselves admitted that the Government had introduced many good programs to elevate the living standard of their community but yet to see much improvement across the country. On the contrary, the wealth accumulated by non-Malays as well as non-natives of Sabah and Sarawak beyond RM1 billion personal net worth as shown in many popular magazines has proven to increase both in the number of individuals and its value. Hence, this paper aims to examine Article 153 and its governance on policies for affirmative action against social injustice using historical and legal analysis methods. The findings in this study could justify the position of Article 153 and allegations against it.

\author{
ARTICLE HISTORY \\ Received: 3-10-2021 \\ Revised: 10-11-2021 \\ Accepted: 29-11-2021
}

\section{KEYWORDS}

The special position

Article 153

Historical and legal

analysis methods

Affirmative action

Malay and Natives of

Sabah and Sarawak

\section{INTRODUCTION}

After more than 60 years of independence, the special position of Malays and natives of Sabah and Sarawak being the sons of the soil still becomes a national debate. Such a position has been lawfully accorded according to our constitutional provision as stipulated in Article 153. In the early years of the 1990s, some quarters had argued about the implementation of the policy without disputing its existence.

Such attitude could be understood looking at the fact that only a small number of Malays had benefitted from the special position. Many Malays themselves admitted that the Government had introduced many good programs to elevate the living standard of their community but yet to see much improvement across the country. Malays later started to argue about the effective implementation of those programs, and many believed that policies created under Article 153 mainly benefitted a few among those in the ruling Government. On the contrary, the wealth accumulated by non-Malays as well as non-natives of Sabah and Sarawak beyond RM1 billion personal net worth as shown in many popular magazines has proven to increase both in the number of individuals and its value.

Surprisingly, despite so many opportunities enjoyed by that benefited from the Government's economic policy, especially non-Malays and non-natives of Sabah and Sarawak both either in person or corporate enterprise, and directly or indirectly, almost none of them denied any allegations such as unfair racial treatments and discrimination thrown at the Government during the International Convention on Elimination of all Racial Discrimination (ICERD) campaign in 2018 and 2019. On the other hand, no one could deny the existence of many businesses and equity either in private or public listed corporations owned by non-Malays, and non-natives of Sabah and Sarawak but named after proxies to qualify many conditions imposed by the Government economic policy.

ICERD campaign was championed in Malaysia by local people and supported by many international communities, even discussed in the committee on the elimination of racial discrimination in the United Nations. The literature review conducted on this subject matter more focused on the issue of discrimination and unfair treatment against other communities in Malaysia. Many writers rely on the "so called" social contract to argue this sensitive issue. For example, Ayu Nor Azila Mohamad et al. (2019) had put up tolerance adopted by Malays to justify policies under Article 153. Another article written by Suzy Aziziyana Saili et al. (2018) blamed the economic policy introduced by the British before Independence day, causing social conflict among Malay and other communities, especially Chinese and Indians. The above are the common arguments on Article 153. So far, no proper research had focused on the existing economic structure within the Malays community before the British advisors introduced many unfavourable policies to Malay entrepreneurship.

This paper does not intend to analyse the implementation of all policies under Article 153. However, some suggestions are put forward in this paper based on an observation made by Wan Ahmad Fauzi (2020) upon the current implementation of those policies for in-depth analysis in future. Hence, this paper aims to examine Article 153 and its governance on 
policies for affirmative action against social injustice using historical and legal analysis methods. The findings in this study could justify the position of Article 153 and allegations against it.

\section{THE HISTORICAL BACKGROUND}

The subject of His Highness the Ruler of a state is defined in the Federation of Malaya Agreement, 1948 as an aboriginal tribe resident in any of the Malay states; or a Malay born in that state, or born outside the Malay states of a father who was, at the time of the birth of such person, a subject of the Ruler of that state; or a person naturalised as a subject of that Ruler under any law for the time being in force. Accordingly, the word 'Malay' is defined thereunder as a person who habitually speaks the Malay language; and professes the Muslim religion, and conforms to Malay custom.

In the present era, the subject of His Highness the Ruler of a state connotes a nationality of a person. Under the Federation of Malaya Agreement, 1948, a common nationality of all subjects of the Malay rulers was formed and by the operation of law named after a Federal citizen of Malaya. In addition, any British subject and a person born in the Strait Settlements of Malacca and Penang and any territory comprised in the Federation of Malaya with specific qualifications are eligible to be admitted as a Federal citizen. Provisions had been made in the aforesaid Agreement to stipulate the admission of any other person into Federal citizenship.

Despite the Federal citizenship provisions as stipulated above, the Federation of Malaya Agreement, 1948 expressly guaranteed the special position of Malays and placed the same under the special responsibility of the High Commissioner of Malaya. The particular provision reads, "the safeguarding of the position of the Malays and the legitimate interest of other communities; " The above policy originated from the State Agreement, 1948 signed between the British Government and respective Malay Rulers on 21 January 1948, that imposed on the Government of every state as a particular charge to provide for and encourage the education and training of the Malay inhabitants to fit them to take a full share in the economic progress, social welfare and Government of the state and the Federation.

The above policy had become the responsibility of the Government at the state as well as Federal level due to the weakness of the previous economic policy introduced by the British advisors of the Malay states in upholding the social justice for Malays at large. The British started to intervene in internal affairs in the Malay states after they had acquired such authority through various agreements signed with the Malay Rulers. The British intervention was first initiated by Francis Light in Penang in the late $18^{\text {th }}$. Century. With such authority, the British designed economic policy to cater to the need of their economic prosperity and political expansion; hence, it placed the British and their allies' interests far above local inhabitants, dominantly Malays.

Traditionally, nobles and chiefs were not only the ruling class in the Malay community. They were also doing trade business where their people served them. According to Wan Ahmad Fauzi (2021), Malaya had become the international trading nation when the Malay Empire of Malacca embraced Islam as the law of the land or even much earlier. The Malay kingdom since the Srivijaya era was popularly known as the maritime state. The nobles and local chiefs previously dominated the traditional economic system. However, the British had gradually taken over economic interests in every Malay state.

The above process took place through the centralisation of the traditional political system under the ultimate authority of the Sultan that previously recognised each local authority with certain autonomy that resided in the nobles and local chiefs. Under the pretext and pretence for good Government, British advisors assumed many authorities of the nobles and local chiefs in the name of a Malay ruler. Consequently, the nobles and local chiefs lost their power and right to collect revenues within their local jurisdiction. Many political and administrative posts attached to the traditional Malay political system vis-à-vis the Malay royal institution had been retired with a pension and become ceremonial. Those posts and their obligations were re-assigned under a new system, so-called state public service.

Simon (1995: 2) comments J.M. Gullick's works on the Indigenous Political System of Western Malaya and Malay Society in the Late Nineteenth Century as follows:

He argues that in the pre-colonial period, except for Sultan Ahmad of Pahang, the Malay Rulers 'resigned all power to turbulent chiefs'. In these circumstances, Sultan tended to control only the royal district in which they resided. While focusing upon the ideological and cultural foundation of Malay political thinking rather than the functions of political institutions,

Simon (1995: 3-5) further comments as follows:

What Britain found when she began to extend her Malayan empire in the 1870s was a series of territories in which tangible power resided essentially in district chiefs, while the nominal Ruler, the Sultan, enjoyed a primarily ceremonial and symbolic role. The unchecked lawlessness which this situation tended to produce encouraged the British to consider ways of re-establishing order. ..... On the one hand, Malay monarchies had had a long history of assimilating foreign traders and warriors, and the accommodation which they reached with the British in the second half of the nineteenth century can be seen in the context. On the other hand, British intervention did result in a tangible alteration in the position of the Malay Rulers. For example, they were placed firmly in a position of authority over the chiefs in their states. More particularly, all revenues of the state were collected in the name of the Sultan, as opposed to the former practice, which saw chiefs collecting and keeping revenue gathered in their district. At the same time, the British ensured that there was a concomitant increase in the wealth and honours of the Sultan. 
This new political structure had consequently eliminated the influence of the nobles and local chiefs in the Malayan economic ecosystem. The implication of the new political structure was far-reaching to the economic and social life of Malays. The nobles and the local chiefs were no longer seen to be powerful. Thus sometimes, they fell into conflicts with the British officers appointed by the Government. To avoid unnecessary conflicts, the Government, on the advice of British advisors, permitted the influx of foreign capitalists to develop many new industries in Malaya without the participation of local entrepreneurs, who were mainly nobles and local chiefs.

Many new business enterprises such as plantation, mining, and trading rapidly grew without the local content as effective managers and shareholders. Not only does the ownership of the new business enterprises belong to foreigners, but its ecosystem also disfavored the participation of local entrepreneurs. Malays who were popularly known as exporters, importers, inter-island traders, suppliers to international entre-port trading, and business enterprises proprietors for hundreds of years were economically left behind. As a result, Malays had been unfairly marginalised in their own land, and the local economy was monopolised by the British and their allies. British subjects and their allies who controlled the business enterprises had further ignored the economic life of ordinary Malays.

The new political structure had caused the nobles and local chiefs no longer to be actively and directly involved in business enterprise. Instead, the majority of them were employed as government officers and clerks. Ordinary Malays were offered lower ranks of staff, whereas many others continued as traditional fishermen and peasants. Very few managed to take some shares in a business enterprise.

The British policy adopted in the Malay states had ruined the traditional structure of local economic life. British foreign interests resulted in a large number of foreign capitalists and investors and foreign labourers being brought in. The British who had been entrusted as advisors in the Malay states failed to provide an opportunity for local entrepreneurs to participate in a new Malayan economic ecosystem in the form of joint ventures with its stakeholders. They might do so either intentionally or unintentionally to acquire the maximum profit for themselves and their allies at the expense of local inhabitants.

The above-mentioned regulated actions denied the economic opportunity to local entrepreneurs on equal terms. While the nobles and local chiefs had lost their rights and autonomy within their respective jurisdiction without adequate compensation, the foreign capitalists enjoyed mining and logging concession and land for plantation through direct dealing with the Government. Such circumstances, in the end, had adversely led to social disparity and economic injustice between the Malays and foreign capitalists.

It is undeniable that the economic activities have contributed to the development of infrastructure, modern administration, and social services in Malaya. The development of infrastructure, modern administrative systems, and social services established before Hari Merdeka was intended to support the British interests in economic activities as a whole in Malaya. Another implication was the status of a stateless person in the Malay states as a result of the demand for foreign labourers in many local business enterprises. In addition, the Atlantic Charter, 1941 required the restoration of sovereign rights and self-government against the wishes of the local inhabitants. Therefore, when the British came back to Malaya in 1945, the special position of Malays was placed under the specific responsibility of the High Commissioner of the Federation. In the premises, the Malay Rulers also agreed that the legitimate interests of other communities who would be accepted as Federal citizens should be maintained.

\section{THE CHALLENGES}

The reality we have today shows that the economic opportunity and wealth distribution in Malaysia are still dominated by non-Malays and non-natives of Sabah and Sarawak. Many policies introduced according to Article 153 do not deprive non-Malays and non-natives of Sabah and Sarawak of the opportunity to acquire wealth, even continuing to indirectly benefit them. Based on FORBES, only three Malays appeared in the 2021 Malaysia's 50 richest men.

The commitment promised by Tan Cheng Lock (Tun) in Memorandum on the 1946 Constitutional Proposal for Malaya needs to be reminded so that the generosity of the Malays in admitting the British subject and stateless person as Federal citizen is not simply ignored when discussing the provision of Article 153. Tan Cheng Lock writes:

44. Lastly, the assurance may be re-iterated here that the non-Malay communities recognise the special position of the Malays in which regard the non-Malays are willing and will heartily co-operate in every way with them to safeguard the vital interests of the Malays, especially with a view to the bringing about of the economic, political, and social advancement of our Malay brethren, which is essential to the establishment of a proper equilibrium between the different communities in the economy of this country to evolve in the effluxion of time a truly contented and prosperous Malaya as one country and one nation, which should be the ideal of all right-minded persons who have the true interests of this land at heart.

The Malay Rulers as the supreme authority in the Malay states that legitimised the Federal Constitution of Malaya, 1957 had stipulated the governance for Article 153 when Their Royal Highnesses stated their view in Their Memorandum dated 12 September 1956 as follows:

\section{Section 6: Matters of Special Responsibility}

12. As to the special position of the Malay, Their Highnesses consider that there are four aspects of the problem; these are land reservation, an appointment to office; educational privileges; and economic privileges. 
13. It is Their Highnesses' considered view that at present and in the foreseeable future, it will be necessary to provide constitutional protection for people of Malay race in respect of each of those matters, but Their Highnesses look forward to a time not too remote when it will become possible to eliminate communalism as a force in the political and economic life, and when because of the relatively high rate of progress which the people of Malay may make under the protection conferred upon them, it will be unnecessary in whole or part to retain these special provisions. For this reason, it is considered that constitutional provision should be made whereby the matter of special privileges other than land reservation can periodically be reviewed.

The above view was similar to the stance made by their Royal Highnesses under the State Agreement, 1948, about the interests of Malays before British subjects and stateless people were accepted as Federal citizens.

The success of policies authorised by Article 153 depends heavily on their implementation as well. Major media in Malaysia reported that the Anti-Corruption Commission (MACC) had identified government departments believed to be involved in a multi-billion Ringgit Malaysia project tender cartel. The Straits Times (NST) on 4 May 2021 said that in February 2021, MACC arrested eight individuals, including its mastermind and a senior government agency officer. NST further reports as follows:

In the raid, the Commission found RM3.5 million cash in the house of a 47-years-old businessman with a 'Datuk' title who allegedly headed the cartel. Sources close to the investigation said RM15.7 million worth of luxury vehicles, which included several Mercedes-Benz models and Range Rovers, were seized. The source added that RM29 million worth of properties, such as bungalows, shophouses, and offices, were also confiscated. A total of 644 accounts have been frozen, belonging to individuals and companies, worth about RM100 million. The mastermind of the cartel had reportedly been monopolising government tenders since 2014.

Such corruption practice has failed the Government's efforts to uplift the economic life of the Bumiputera through affirmative action plans, citing a syndicate that monopolised 345 tenders with the worth of RM3.8 billion. According to the FMT report on 8 April 2021, Bumiputera contractors were the most affected by the above syndicate. Without the practice of world-class good governance ethics as propounded by Wan Ahmad Fauzi (2020), the core problems are hard to resolve. The core problems are the conduct of management and personal behaviour within the business community. The conduct of management and behaviour within an organisation or individual personality must comply with the principles of faith, accountability, disruptive leadership, integrity, trustworthiness underpinned with consultation towards justice. That is the essence to combat all corrupt practices.

The above illustrates the undisputed challenges towards implementing various policies under New Economic Policy, 1971, and possible threats to Shared Prosperity Vision 2030.

\section{ARTICLE 153}

Article 153 places a duty on the Yang di-Pertuan Agong not only to safeguard the special position of Malays and natives of Sabah and Sarawak, even the legitimate interests of other communities being the citizens of Malaysia under the provisions herein. The rationale of legislating Article 153 has been historically viewed in this paper.

The Yang di-Pertuan Agong shall exercise his functions under the Federal Constitution and federal law in such a manner as necessary to safeguard the special position of Malays and natives of Sabah and Sarawak. The Yang di-Pertuan Agong needs to ensure the reservation for Malays and natives of Sabah and Sarawak of such proportion as he may deem reasonable of positions in the public service (other than the public service of a State) and of scholarships, exhibitions and other similar educational or training privileges or special facilities given or accorded by the Federal Government and when any permit or license for the operation of any trade or business is required by federal law.

In order to ensure the reservation of the above, the Yang di-Pertuan Agong may give such general directions as may be required for that purpose to any Commission to which Part X of the Federal Constitution applies or to any authority charged with responsibility for the grant of such scholarships, exhibitions or other educational or training privileges or special facilities.

In exercising his functions under Article 153, the Yang di-Pertuan Agong shall not deprive anyone of any public office held by him or of the continuance of any scholarship, exhibition or other educational or training privileges or special facilities he enjoys. Whereby existing federal law a permit or license is required for the operation of any trade or business, the Yang di-Pertuan Agong may exercise his functions under that law in such manner, or give such general directions to any authority charged under that law with the grant of such permits or licenses, as may be required to ensure the reservation of such proportion of such permits or licenses for Malays and natives of Sabah and Sarawak as the Yang diPertuan Agong may deem reasonable.

Article 153 does not operate to deprive or authorise the deprivation of any person of any right, privilege, permit or license accrued to or enjoyed or held by him or to authorise a refusal to renew to any person any such permit or license or a refusal to grant to the heirs, successors or assigns of a person any permit or license when the renewal or grant might reasonably be expected in the ordinary course of events. Whereby any federal law, any permit or license is required for the operation of any trade or business, that law may provide for the reservation of a proportion of such permits or licenses for Malays and natives of Sabah and Sarawak, but no such law shall be enforced for the purpose of ensuring such a reservation could be enforced as follows: 
1. Deprive or authorise the deprivation of any person of any right, privilege, permit or license accrued to or enjoyed or held by him; or

2. Authorise a refusal to renew to any person any such permit or license or a refusal to grant to the heirs, successors or assigns of any person any permit or license when the renewal or grant might be in accordance with the other provisions of the law reasonably be expected in the ordinary course of events, or prevent any person from transferring together with his business any transferable license to operate that business; or

3. Where no permit or license was previously required for the operation of the trade or business, authorise a refusal to grant a permit or license to any person for the operation of any trade or business which immediately before the coming into force of the law he had been bona fide carrying on, or authorise a refusal subsequently to renew to any such person any permit or license, or a refusal to grant to the heirs, successors or assigns of any such person any such permit or license when the renewal or grant might in accordance with the other provisions of that law reasonably be expected in the ordinary course of events.

Where in any university, college and other educational institution providing education after Malaysian Certificate of Education or its equivalent, the number of places offered by the authority responsible for the management of the university, college or such educational institution to candidates for any course of study are less than the number of candidates qualified for such places, it shall be lawful for the Yang di-Pertuan Agong by virtue of Article 153 to give such directions to the authority as may be required to ensure the reservation of such proportion of such places for Malays and natives of Sabah and Sarawak as the Yang di-Pertuan Agong may deem reasonable.

Finally, Article 153 does not empower Parliament to restrict business or trade solely for the purpose of reservations for Malays and natives of Sabah and Sarawak. The special provision of Malay and natives of Sabah and Sarawak are also provided in the state constitution of respective states.

\section{AFFIRMATIVE ACTIONS}

What is more important and needs to be given real focus is the method of executing policies under Article 153. Governance needs to be reviewed to ensure that no Malaysian is denied legal protection and the right to basic necessities. In this regard, the Federal Constitution places special responsibility to the Yang di-Pertuan Agong and defines its mechanism as stipulated therein to safeguard the special position of Malays and natives of Sabah and Sarawak and the legitimate interests of other communities.

For the above purpose, the Government can take a strategic approach by looking at a broader framework. It is suggested a layered approach to restructuring the socio-economy of Malaysian as a whole. The Government may divide Malaysians not employed by the Federal Government, State Governments, and their agencies into three significant layers based on the socio-economic assessment as follows:

1. Major corporations and business enterprises; the Government may establish joint ventures, collaboration, incentives, and investment opportunities for Malay, Natives of Sabah and Sarawak and the indigenous people corporates who are competent and eligible to increase their net worth until there is a balance of ethnic composition in the list of 100 richest people in Malaysia.

2. Middle-class strata: the Government may create joint ventures, collaboration, incentives, and working opportunities for Malay, Natives of Sabah and Sarawak, and the indigenous people entrepreneurs who are competent and eligible to increase their incomes and better employment policy to close the social gap among races.

3. Group in dire need; the Government need to formulate policies regardless of religious and racial divides to uplift members within this group out of hardcore poverty through educational, vocational, and appropriate training assistance schemes.

The above approach is indeed in line with one of the principles of Islam, namely 'rahmatan lil 'alamin', which means mercy for the world. Islam as a religion of 'rahmatan lil 'alamin' is based on the 'maqasid as-syariah' placing universal values that need to be upheld for the sake of justice for all. 'Maqasid as-syariah' means the objective of Islamic law is to preserve faith, life, intellect, lineage, and property. The preservation of these elements represents every aspect of human life given protection by Islam regardless of religion, lineage, nation, ethnicity, and standard of living in society. The above principles come together with the position of Islam as the religion of the Federation (Wan Ahmad Fauzi, 2021a).

\section{CONCLUSION}

Article 153 of the Federal Constitution legalises affirmative policy and executive action to balance the economic life and improve social disparity for the well-being of Malaysian at all levels within society. The 13 May 1969 tragedy should be remembered as a lesson. Every citizen should learn and appreciate our nation-building that witnessed great compromise by the Malay Rulers and their subjects too.

It must be understood that Article 153 guarantees the legitimate interests of other communities as well. Article 153 provides the governance of how policies thereunder are to be regulated and administered. Additionally, the Federal Constitution contains other provisions to prevent injustice and oppression against any fellow Malaysian. Indeed, national unity can only be established in the spirit of Malaysian should every party uphold the supremacy of our Federal Constitution. 
Last but not least, the policy under Keluarga Malaysia must always take account into the above governing principles. Today, many people are still misled to believe that Malays were 'orang hutan duduk di atas pokok' (jungle people living on trees) before the coming of the British, and thus owed everything to the colonial masters for their civilisation. This perception gradually developed a school of thought named after colonial knowledge. It is hoped that this paper will suffice to answer many issues in question.

\section{REFERENCES}

Allen, J. de, Stockwell, A. J. \& Wright, L. R. (Ed.) 1981. A Collection of Treaties and Other Documents Affecting the States of Malaysia. Jil. 2. London: Oceana Publication.

Ayu Nor Azilah Mohamad, Mohamed Ali Haniffa, Wayu Nor Asikin Mohamad. Toleransi Orang Melayu Mengharmonikan Pemajmukan Kaum di Malaysia. Vol 18, No. 2(2019): Oktober 2019.

C.C. Brown (Translated from MS Raffles). Malay Annals. 2010. Kuala Lumpur: MBRAS.

Perlembagaan Persekutuan. 2010. Kuala Lumpur: Pesuruhjaya Penyemak Undang-Undang Malaysia.

Saili, S.A., Mohd Hussain, R.B. and Mat Karim, K (2018) "Peranan Jawatankuasa Perhubungan Kaumdalam Merintis Kesepaduan Sosial di Tanah Melayu: Satu Tinjauan Awal bagi Model Masa Depan”, Malaysian Journal of Science and Humanities (MJSSH), 3(3), pp. 160-167.

Simon C. Simon. 1995. British Relations with the Malay Rulers from Decentralisation to Malayan Independence 1930-1957. Kuala Lumpur: Oxford University Press.

Wan Ahmad Fauzi Wan Husain. 2021. Yang Di-Pertuan Agong: Kedaulatan, Prerogatif dan Amalan. Kuala Lumpur: Dewan Bahasa dan Pustaka.

Wan Husain, W. A. Fauzi (2021). Insight: The Interpretation of Islam Within the Legal Framework of the Indigenous Malaya. Journal of Governance and Integrity, 4(2), 64-72.

Wan Ahmad Fauzi Wan Husain. 2020. Kenegaraan Malaysia: Sejarah, Kedaulatan dan Kebangsaan.

Wan Husain, W. A. Fauzi (2020). Insight: The Conceptual Framework For Buiding The World-Class Good Governance Ethics. Journal of Governance and Integrity, 4(1), 1-5.

\section{CONFLICT OF INTEREST}

The author(s), as noted, certify that they have NO affiliations with or involvement in any organisation or agency with any financial interest (such as honoraria; educational grants; participation in speakers' bureaus; membership, jobs, consultancies, stock ownership, or other equity interest; and expert testimony or patent-licensing arrangements), or nonfinancial interest (such as personal or professional relationships, affiliations, expertise or beliefs) in the subject matter or materials addressed in this manuscript.

\section{AUTHORS' BIOGRAPHY}

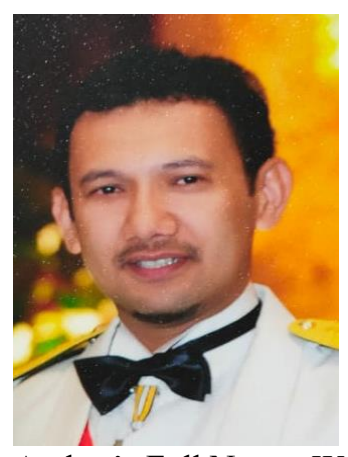

Author's Full Name: Wan Ahmad Fauzi Wan Husain

Author's Email: wanfauzi@ump.edu.my

Author Professional Bio:

Wan Ahmad Fauzi was admitted as an advocate \& solicitor at the High Court of Malaya, Kuala Lumpur on 23 September 1996. He is also qualified as a Syar'ie counsel for the State of Terengganu and the Federal Territories. In 2012, he was listed in "The Book of Malaysia Leaders: Political, Government \& Corporate. He once held a few prominent posts such as the Secretary of Terengganu Council of The Royal Court. At presence, he actively involves in NGOs. He obtained his $\mathrm{PhD}$ in constitutional law together with the certificates of Graduate on Time and Distinction PhD Thesis from the Law Faculty of The National University of Malaysia. Wan Ahmad Fauzi is the founder of Watan Jurisprudence. In recognizing his great contribution to our country, he was conferred a few Royal Awards such as PJN., DPNS., SMT. 